\title{
Optimalisasi Teknik Ekstraksi dan Isolasi DNA \\ Tanaman Suren (Toona Sureni Merr.) untuk Analisis Keragaman Genetik berdasarkan Random Amplified Polymorphic DNA (RAPD)
}

\author{
Muh. Restu*), Mukrimin dan Gusmiaty \\ Fakultas Kehutanan, Universitas Hasanuddin, Makassar 90245 \\ Diterima 10-05-2011_ Disetujui 13-02-2012
}

\begin{abstract}
The species of trees have different secondary compounds that need optimum extraction techniques. Appropriate extraction techniques determine the quality and quantity of DNA produced. This research aims to found optimal of extraction methods and DNA isolation, then to created genome DNA in high quality and quantity, so that it can be using for genetic variation analyses in Suren (Toona sureni Merr.) by Random Amplified Polymorphic DNA (RAPD). This study shows that DNA concentrates were $763.3 \mathrm{~g} / \mathrm{ml}, 180.0 \quad \mathrm{~g} / \mathrm{ml}, 383.3 \mathrm{~g} / \mathrm{ml}$, and $436.7 \mathrm{~g} / \mathrm{ml}$. While based on the results of PCR amplification using the primers OPD 03 shows that the four extraction methods used, the extraction method of number 3 has been able to produce genomic DNA with better quality and more number of bands, although the quantity is lower.
\end{abstract}

Keywords: CTAB, DNA extraction, Toona sureni

\begin{abstract}
ABSTRAK
Setiap jenis tanaman memiliki kandungan senyawa sekunder yang berbeda-beda sehingga membutuhkan teknik ekstraksi yang optimum. Teknik ekstraksi yang tepat sangat menentukan kualitas dan kuantitas DNA yang dihasilkan. Penelitian ini bertujuan untuk mendapatkan metode ekstraksi dan isolasi DNA yang optimal dan menghasilkan DNA genom yang berkualitas baik serta jumlah yang memadai sehingga dapat digunakan untuk analisis keragaman genetik pada tanaman suren (Toona sureni) berdasarkan Random Amplified Polymorphic DNA (RAPD). Hasil penelitian menunjukkan bahwa rata-rata konsentrasi DNA dihasilkan pada metode 1, 2, 3 dan 4 adalah berturut-turut 763,3 g/ml; 180,0 g/ml; 383,3 g/ml dan 436,7 g/ml. Berdasarkan hasil amplifikasi PCR menggunakan primer OPD 03 menunjukkan bahwa dari keempat metode ekstraksi yang digunakan, metode ekstraksi 3 mampu menghasilkan DNA genom dengan kualitas yang lebih baik dan jumlah pita yang lebih banyak walaupun kuantitas yang lebih rendah.
\end{abstract}

Kata Kunci : CTAB, Ekstraksi DNA, Toona sureni

\section{PENDAHULUAN}

Studi genetik terutama studi populasi genetik terhadap jenis tumbuhan hutan tropis berlangsung sangat lambat, disebabkan oleh banyak kesulitan yang menghambat seperti penyediaan sampel segar setelah dibawa dalam perjalanan jauh sering menginduksi senyawa fenol dan polisakarida pada jenis tumbuhan berkayu. Senyawa-senyawa tersebut dapat mengontaminasi sediaan DNA dan akan menghambat analisis lebih lanjut. Ekstraksi untuk mendapatkan DNA berkualitas tinggi merupakan satu kaidah dasar yang harus dipenuhi dalam analisis molekuler. Masalah-masalah dalam ekstraksi DNA masih merupakan hal penting yang perlu diatasi.

\footnotetext{
*Telp : +62811443515

e-mail: tueid@yahoo.com
}

Berbagai teknik analisis dalam pemuliaan tanaman dan biologi molekuler yang berdasarkan pada hibridisasi molekuler atau Polymerase Chain Reaction (PCR) membutuhkan DNA dalam jumlah yang cukup dan kualitas yang baik. Oleh karena kandungan senyawa sekunder dalam sel tanaman berbeda-beda, maka setiap tanaman membutuhkan prosedur isolasi yang optimum agar diperoleh DNA genom yang dapat digunakan sebagai bahan dalam analisis molekuler. Optimasi prosedur tersebut dapat dilakukan terhadap komposisi larutan buffer lisisnya ataupun teknik penanganan fisik dalam pemisahan DNA genom dari senyawa lain. Pada prinsipnya optimasi prosedur ini bertujuan melindungi DNA genom dari degradasi akibat senyawa sekunder yang dilepaskan ketika sel dihancurkan atau kerusakan akibat penanganan fisik (Milligan 1992). 
Beberapa teknik dan prosedur telah dipublikasikan, tetapi seringkali tidak dapat diaplikasikan karena genus atau bahkan spesies tanaman bersifat sangat spesifik. Modifikasi metode standar ekstraksi DNA diperlukan pada ekstraksi DNA dari daun tanaman yang mengandung banyak polisakarida atau metabolit sekunder. Ekstraksi DNA daun tanaman Grevillea (Proteaceae) dengan memodifikasi metode Doyle dan Doyle (1990), telah berhasil diperoleh DNA dengan kualitas yang baik (Pharmawati 2009). Metode isolasi DNA tanaman bitti (Vitex cofassus) dengan menggunakan metode Lengkong et al. (1998) dalam Masniawati (2000) berdasarkan penelitian Pratama (2009) memperlihatkan hasil ekstraksi DNA yang kurang optimal baik kualitas maupun kuantitas DNA yang dihasilkan sehingga mempengaruhi intensitas pita DNA hasil amplifikasi yang tidak jelas. Hal tersebut menunjukkan bahwa metode isolasi DNA yang telah dilakukan pada tanaman padi tidak dapat diaplikasikan secara maksimal pada tanaman lain khususnya jenis tanaman kehutanan. Oleh karena itu pemilihan dan optimalisasi metode isolasi yang memungkinkan diperolehnya DNA genom tanaman suren (Toona sureni) perlu dilakukan.

Penelitian mengenai metode isolasi DNA tanaman kehutanan khususnya suren (Toona sureni) merupakan langkah awal yang akan digunakan sebagai referensi untuk penelitian-penelitian selanjutnya. Penelitian ini bertujuan untuk mendapatkan metode ekstraksi dan isolasi DNA yang optimal dan menghasilkan DNA genom yang berkualitas baik serta jumlah yang memadai sehingga dapat digunakan untuk analisis keragaman genetik pada tanaman suren (Toona sureni) berdasarkan Random Amplified Polymorphic DNA (RAPD).

\section{BAHANDANMETODE}

Penelitian ini dilaksanakan di Laboratorium Silvikultur Fakultas Kehutanan Unhas dan Laboratorium Bioteknologi, Pusat Kegiatan Penelitian Unhas, berlangsung mulai bulan Juni hingga November 2010. Bahan yang digunakan adalah sampel daun muda tanaman suren yang diperoleh dari lokasi sekitar Kampus Unhas. Bahan lain yang digunakan adalah nitrogen cair, buffer ekstraksi CTAB, PVP, agarose, loading dye, TAE, megamix blue, 100 bp DNA ladder, dan primer OPD 03. Alat yang digunakan adalah timbangan analitik, lemari es dan freezer, $\mathrm{pH}$ meter, mortar dan pestel, spatula, gunting, pipet ukur, pipet mikro, tips, tabung mikrosentrifus, mesin elektroforesis (BioRad),vortex, mesin PCR (Applied Biosystem), waterbath, mesin sentrifugasi, gel doc.

Ekstraksi DNA. Metode 1, dilakukan berdasarkan metode dari Doyle dan Doyle (1987) dalam Ardiana (2009) yang dimodifikasi. Sebanyak $200 \mathrm{mg}$ sampel tanpa tulang daun ditambah PVP 0,02 g digerus dengan nitrogen cair hingga halus (tepung). Selanjutnya hasil gerusan dipindahkan ke dalam tabung eppendorf ukuran 1,5 ml, lalu ditambah 0,5 $\mathrm{ml}$ bufer ekstraksi CTAB (1,4 M NaCl, 2\% CTAB, 50 mM EDTA, 1 M Tris- $\mathrm{HCl}$ pH 8,0 dan 0,2\% ß-mercaptoetanol). Proses lisis dinding sel dilakukan dengan menginkubasi tabung berisi sampel daun ke dalam waterbath suhu $65^{\circ} \mathrm{C}$ selama 60 menit. Tabung diangkat dari waterbath dan dibiarkan beberapa menit sampai suhu sampel dalam tabung menurun. Selanjutnya ditambah khloroform: isoamilalkohol (CIA 24:1) 500 1. Tabung dikocok menggunakan vortex, kemudian disentrifugasi pada kecepatan $10.000 \mathrm{rpm}$ selama 10 menit. Supernatan dipindahkan ke dalam tabung bar lalu ditambahkan isopropanol dingin sebanyak 1 volume, dibolak-balik perlahan hingga tampak benang DNA. Sampel kemudian dibiarkan mengendap selama semalam dalam lemari pendingin pada suhu $4^{\circ} \mathrm{C}$. Setelah diendapkan semalam, sampel kemudian disentrifugasi selama 15 menit pada kecepatan 10.000 rpm. Pellet DNA yang terbentuk di dasar tabung kemudian dikering udarakan. Setelah itu ditambahkan $100 \mu \mathrm{l} \mathrm{dd}_{2} \mathrm{O}$ dan disimpan dalam lemari pendingin $\left(-4^{\circ} \mathrm{C}\right)$.

Metode 2, proses ekstraksi sama dengan metode 1, yang berbeda hanya konsentrasi Tris dan EDTA yang sama dengan metode 3 (100 mM Tris $\mathrm{HCl}$ dan 20 mM EDTA).

Metode 3, Sebanyak $200 \mathrm{mg}$ sampel daun muda digerus hingga halus lalu ditambahkan $500 \mu \mathrm{l}$ buffer CTAB (100 mM Tris $\mathrm{HCl}$ pH 8,0; 1,4 M NaCl; 20 mM EDTA; 2\% CTAB; $0,2 \%$ B-mercaptoetanol), divortex selama 15 menit dan diinkubasi dalam waterbath pada suhu $65^{\circ} \mathrm{C}$ selama 60 menit. Selanjutnya ditambah kloroform $100 \mu 1$ dan disentrifugasi pada 10.000 rpm selama 5 menit. Supernatan dipindahkan ke dalam tabung baru dan ditambahkan $800 \mu$ l isopropanol dan diendapkan semalam pada suhu $4^{\circ} \mathrm{C}$. Sentrifugasi pada kecepatan 10.000 rpm selama 10 menit. Endapan DNA yang diperoleh, dikeringkan pada suhu $37^{\circ} \mathrm{C}$ selama 15 menit. Purifikasi dilakukan dengan menambahkan $500 \mu \mathrm{l}$ buffer TE 1x (10 mM Tris-HCl pH 7,5; 1 mM EDTA) dan $100 \mu l$ fenol, lalu dibolak-balik secara perlahan. Selanjutnya disentrifugasi selama 10 menit pada kecepatan 10.000 rpm. Supernatan 
dipindahkan ke dalam tabung eppendorf baru dan ditambahkan $100 \mu 1$ kloroform lalu dibolak-balik. Selanjutnya disentrifugasi pada kecepatan 10.000 rpm selama 10 menit. Supernatan diambil lalu ditambahkan $100 \mu 1$ natrium asetat $3 \mathrm{M}$ dan $800 \mu \mathrm{l}$ isopropanol, lalu disentrifugasi selama 10 menit pada kecepatan $10.000 \mathrm{rpm}$. Endapan diambil dan

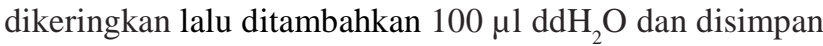
dalam lemari pendingin $\left(-4^{\circ} \mathrm{C}\right)$.

Metode 4, proses ekstraksi sama dengan metode 3, yang berbeda hanya konsentrasi Tris dan EDTA sama dengan metode 1 (1 M Tris $\mathrm{HCl}$ dan 50 mM EDTA).

Pengukuran Konsentrasi DNA. Nilai konsentrasi sampel DNA hasil ekstraksi diukur dengan mengambil $50 \mu \mathrm{l}$ sampel pada masing-masing tahap. Sampel dipipet pada plat spektrofotometer untuk memperoleh OD (Optical Density). Pada spektrofotometer digunakan metode panjang gelombang tunggal (Single Wave Length) dan OD diukur pada panjang gelombang $260 \mathrm{~nm}$. Untuk mengetahui konsentrasi DNA dari nilai OD sampel digunakan persamaan:

Konsentrasi DNA $(\mathrm{g} / \mathrm{ml})=\mathrm{A}_{260} \times 50 \times$ Faktor Pengenceran.

Amplifikasi DNA Genom dengan Teknik PCR. DNA genom tanaman suren diamplifikasi menggunakan primer acak yang terdiri dari 10 basa (OPD 03). Total volume reaksi yang digunakan adalah $25 \mu \mathrm{l}$ yang terdiri dari 16,88 $\mu 1$ mega mix blue, 5,62 $\mu 1$ primer ( 10 pmol) dan 2,5 $\mu$ l cetakan DNA. Selanjutnya proses PCR dengan kondisi Pre PCR selama 2 menit pada suhu $95^{\circ} \mathrm{C}$, dilanjutkan dengan tahap PCR selama 40 siklus, terdiri atas denaturasi selama 10 detik pada suhu $95^{\circ} \mathrm{C}$, annealing selama 30 detik pada suhu $35^{\circ} \mathrm{C}$ dan ekstension selama 1 menit pada suhu $72^{\circ} \mathrm{C}$. Setelah 40 siklus selesai, kemudian diikuti final ekstension selama 5 menit pada suhu $72^{\circ} \mathrm{C}$ dan pendinginan pada suhu $4^{\circ} \mathrm{C}$ selama 30 menit.

Elektroforesis Gel Agarosa. Hasil amplifikasi selanjutnya dielektroforesis bersama DNA marker $100 \mathrm{bp}$ (DNA ladder) pada gel agarosa $2 \%$ dan di dalam buffer TAE (Tris-EDTA) selama 40 menit pada 100 volt. Gel kemudian direndam dalam larutan ethidium bromide selama 10 menit. Selanjutnya gel diamati di bawah lampu UV menggunakan Gel documentation system.

\section{HASIL DAN PEMBAHASAN}

Berdasarkan hasil uji kuantitatif dengan menggunakan spektrofotometer menunjukkan bahwa rata-rata konsentrasi DNA dihasilkan pada metode 1, 2, 3 dan 4 adalah berturut- turut 763,3 g/ml; 180,0 g/ml; 383,3 g/ml dan 436,7 g/ml. Sedangkan berdasarkan perbandingan nilai absorbansi $\mathrm{A}_{260} / \mathrm{A}_{280}$ dari keempat metode tersebut yang mendekati tingkat kemurnian yang tinggi dan DNA yang dihasilkan cukup bersih adalah metode 1 dan 2 (Tabel 1). Secara teoritis, sampel DNA yang dianggap cukup murni mempunyai perbandingan $\mathrm{A}_{260} / \mathrm{A}_{280}=1,80-2,0$. Menurut Sambrook et al. (1989), kisaran angka tersebut telah memenuhi persyaratan yang dibutuhkan dalam analisis molekuler.

Metode dengan tahap pemurnian satu kali (metode 1) menghasilkan rata-rata konsentrasi DNA yang tinggi daripada metode 3 dan 4 dengan tahap pemurnian dua kali. Hal tersebut disebabkan karena pada saat pemurnian, sebagian supernatan yang mengandung DNA genom ikut terbuang sehingga konsentrasi DNA yang dihasilkan menjadi berkurang. Berbeda halnya pada metode 2 , walaupun tahap pemurniannya hanya satu kali, namun konsentrasi DNA yang diperoleh paling rendah daripada metode yang lain. Kemungkinan pada saat pengambilan supernatan tidak maksimal sehingga DNA genom banyak yang terbuang.

Berdasarkan hasil amplifikasi dengan menggunakan primer OPD 03 maka pada metode 3, jumlah pita yang dihasilkan lebih banyak dibandingkan dengan metode 1 dan 2 (Gambar 1). Pita yang didapatkan pada metode 1 (lane 2-4) berukuran 150 - 350 bp sebanyak 4 pita, metode 2 (lane 5-7) menghasilkan pita berukuran 150-600 bp sebanyak 5 pita sedangkan metode 3 (lane 8-10) berukuran 150-700 bp sebanyak 6 pita. Adanya perbedaan jumlah pita yang muncul dengan sampel dan primer yang sama kemungkinan disebabkan oleh adanya variasi umur daun yang digunakan dalam proses ekstraksi. Disamping itu pada metode 3, proses purifikasi berlangsung beberapa tahapan sementara pada metode 1 dan 2 proses purifikasinya relatif sederhana sehingga DNA yang dihasilkan tidak dapat diamplifikasi secara maksimal dalam proses PCR.

Bila dihubungkan dengan perbedaan konsentrasi buffer ekstraksi yang digunakan, walaupun konsentrasi DNA yang dihasilkan pada metode 2 dan 3 relatif sedikit dengan penggunaan konsentrasi Tris dan EDTA yang rendah

Tabel 1 Karakter kuantitatif hasil isolasi DNA Tanaman Suren (Toona sureni)

\begin{tabular}{ccc}
\hline Metode & $\lambda_{260} / \lambda_{280}$ & {$[\mathrm{DNA}](\mathrm{g} / \mathrm{ml})$} \\
\hline 1 & 2,1 & 763,3 \\
2 & 2,1 & 180 \\
3 & 4,5 & 383,3 \\
4 & 4,1 & 436,7 \\
\hline
\end{tabular}


dibandingkan dengan metode 1 dan 4 , namun jumlah pita yang dihasilkan lebih banyak. Hal tersebut menunjukkan bahwa dengan penggunaan konsentrasi Tris dan EDTA yang tinggi terbukti tidak dapat diamplifikasi baik bahkan pada metode 4 tidak muncul pita sama sekali.

Hasil amplifikasi PCR juga menunjukkan bahwa dari keempat metode ekstraksi yang digunakan terkecuali metode 4 (lane 11-13) yang tidak dapat diamplifikasi dengan baik. Hal ini ditunjukkan tidak munculnya pita DNA dengan penggunaan primer acak. Tidak teramplifikasinya DNA tersebut disebabkan karena kemungkinan masih terdapat senyawa sekunder dan polisakarida sehingga menghambat kerja enzim dalam proses PCR. Menurut Fang et al. (1992) dalam Porebski et al. (1997), bahwa adanya polisakarida dalam tanaman ditandai dengan kekentalan pada hasil isolasi DNA dapat menyebabkan kesulitan dalam reaksi PCR.

Hasil ekstraksi pada metode 1, 2 dan 3 masing-masing menunjukkan adanya pita DNA dimana pola pita DNA yang dihasilkan memiliki ketebalan yang sama. Hal tersebut menunjukkan bahwa ketiga metode tersebut dapat diamplifikasi dengan baik. Produk ekstraksi DNA yang berkualitas baik ditunjukkan dengan pita DNA yang terlihat tebal dan bersih serta pita DNA yang menyala. Dengan demikian ketiga metode tersebut layak digunakan dalam isolasi DNA genom tanaman suren.

Penambahan senyawa pereduksi seperti merchaptoetanol dalam proses isolasi DNA dapat mencegah proses oksidasi senyawa fenolik sehingga menghambat aktivitas radikal bebas yang dihasilkan oleh oksidasi fenol terhadap asam nukleat (Wilkins \& Smart 1996). Penggunaan CTAB dalam buffer ekstraksi berguna untuk mengeliminasi polisakarida. Selanjutnya Fang et al. (1992) dan Tel-zur et al. (1999), menyatakan bahwa penambahan $\mathrm{NaCl}$ dengan konsentrasi di atas $1 \mathrm{M}$ dapat meningkatkan kelarutan polisakarida sehingga lebih mudah untuk dihilangkan. Dengan demikian, buffer CTAB cukup memenuhi syarat untuk digunakan dalam ekstraksi DNA dari tanaman yang mengandung karbohidrat dan fenol tinggi karena tidak merusak DNA. Buffer CTAB dengan kandungan garam yang tinggi dapat memisahkan polisakarida dari dinding sel, sedangkan PVP dapat mengurangi browning akibat kandungan fenol pada daun muda (Porebski et al. 1997; Surzycki 2000).

\section{SIMPULAN}

Berdasarkan hasil uji kuantitatif dengan menggunakan spektrofotometer menunjukkan bahwa rata-rata konsentrasi DNA dihasilkan pada metode 1, 2, 3 dan 4 adalah berturutturut 763,3 g/ml; 180,0 g/ml; 383,3 g/ml dan 436,7 g/ml. Hasil amplifikasi PCR menggunakan primer OPD 03 menunjukkan bahwa dari keempat metode ekstraksi yang digunakan, metode ekstraksi 3 mampu menghasilkan DNA genom dengan kualitas yang lebih baik dan jumlah pita yang lebih banyak walaupun kuantitas yang lebih rendah.

\section{UCAPANTERIMAKASIH}

Terima kasih kepada Direktorat Jenderal Pendidikan Tinggi, Departemen Pendidikan Nasional yang telah membiayai penelitian ini melalui Surat Perjanjian Pelaksanaan Penelitian Hibah Kompetensi Nomor: 378/PS2H/PP/DP2M/ VI/2010, tanggal 11 Juni 2010.

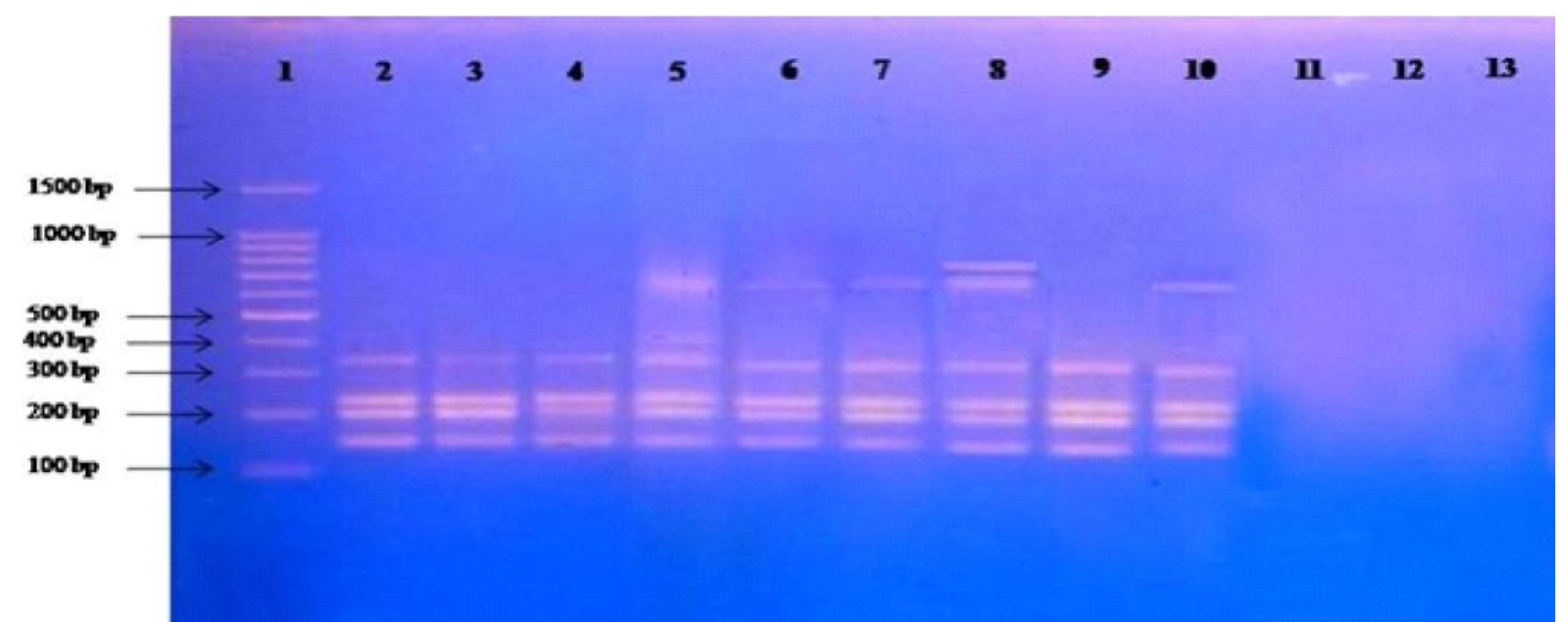

Gambar 1 Pola pita DNA tanaman suren hasil ekstraksi dengan menggunakan primer OPD $03(1=$ Marker, $2=$ M1.1, $3=\mathrm{M} 1.24=\mathrm{M} 1.3$ $5=\mathrm{M} 2.16=\mathrm{M} 2.27=\mathrm{M} 2.3,8=\mathrm{M} 3.1,9=\mathrm{M} 3.2,10=\mathrm{M} 3.3,11=\mathrm{M} 4.1,12=\mathrm{M} 4.2,13=\mathrm{M} 4.3)$ 


\section{DAFTAR PUSTAKA}

Ardiana, D.W. 2009. Teknik isolasi DNA genom tanaman pepaya dan jeruk dengan menggunakan modifikasi buffer CTAB. Buletin Teknik Pertanian 14(1): 12-16.

Doyle, J.J \& Doyle, J.L. 1990. Isolation of plant DNA from fresh tissue. Focus 12: 13-15.

Fang, G.S., Hammer \& R.Grumet. 1992. A quick and inexpensive method for removing polysaccharides from plant genomic DNA. Biotechniques 13(1): 52-57.

Lengkong, E.F., Hartana, A \& Suharsono. 1998. Keragamangenetika beberapa kultivar kelapa berdasarkan penanda RAPD (Random Amplified Polymorphic DNA). Prosiding Seminar Sehari Hasil-hasil Penelitian Bidang Ilmu Hayat. Bogor, 3 September 1998.

Masniawati, A. 2000. Keragaman genetik kelapa dalam mapanget32 (dmt-32) hasil penyerbukan sendiri berdasarkan penanda molekuler random amplified polymorphic DNA (RAPD). Tesis Pascasarjana. Bogor: Institut Pertanian Bogor.

Milligan, B.G. 1992. Plant DNA Isolation. In: A.R. Hoelzel (Ed) Molecular Genetic Analysis of Populations. A Practical Approach. New York: Oxford University Press.

Pharmawati, M. 2009. Optimalisasi ekstraksi DNA dan PCR-RAPD pada grevillea spp. (Proteaceae). Jurnal Biologi 13(1): 12-16.
Porebski, S., Bailey, G.L \& Baum, B.R. 1997. Modification of a CTAB DNA extraction protocol for plants containing high polysaccharide and polyphenol components. Plant Mol Biol Reptr 15(1): 8-15.

Pratama, B.A. 2009. Analisis Keragaman Genetika Bitti (Vitex cofassus Reinw) pada Provenansi Bulukumba Berdasarkan Penanda Molekuler Random Amplified Polymorphic DNA (RAPD). Skripsi Fakultas Kehutanan. Makassar: Universitas Hasanuddin.

Sambrook, J., Fritsch, E.F \& Maniatis, T. 1989. Molecular Cloning. A Laboratory Manual. USA: Cold Spring Harbor Lab Press.

Surzycki, S. 2000. Basic Techniques in Molecular Biology. Berlin, Heidelberg, New York: Springer-Verlag.

Tel-zur, N., S., Abbo, D., Myslabodski \& Mizrahi, Y. 1999. Modified CTAB procedure for DNA isolation from epiphytic cacti of genera hylocereus and selenicereus (Cactaceae). Plant Mol Biol Reptr 17: 249-254.

Wilkins, T.A \& Smart, L.B. 1996. Isolation of RNA from Plant Tissue. Di dalam: Krieg, P.A. (ed). A Laboratory Guide to RNA. Isolation, Analysis and Synthesis. New York: Wiley-Liss. 